\title{
Fodder for Change: Animals, Urbanisation, and Socio-Economic Transformation in Protohistoric Italy
}

\author{
Angela Trentacoste \\ University of Oxford, GB \\ angela.trentacoste@arch.ox.ac.uk
}

In central and northern Italy, the first millennium BC was characterised by the rise of urbanism and an expansion of nearly every area of production. Agriculture was no exception, and an increase in the scale and intensity of agricultural production sustained, and was sustained by, economic and population growth. Within this context, animal management also evolved to meet the needs of the changing protohistoric landscape. Pigs grew in importance as meat producers, and a greater emphasis was placed on animal-derived products like wool. These changes can be linked to the subsistence requirements of urban populations and the value of raw materials; however, beyond these functional explanations, the wider socio-economic context of animal husbandry is rarely explored.

This paper aims to bridge the gap between the zooarchaeological evidence for livestock production and the socio-economic transformations that drove animal management. Three aspects of protohistoric husbandry are explored through discussion of pig, cattle, sheep, and chicken exploitation: greater differentiation in livestock production between different site types, specialisation of animals through selective breeding, and the adoption of new forms of livestock. These lines of evidence demonstrate the role of animals in socio-economic networks of distribution and dependence, and they highlight the importance of agricultural produce in the articulation of social hierarchies. As in the transformation of other forms for material culture during this of this period, livestock husbandry regimes were not simply the deterministic result of wider socio-economic change, but a medium actively adapted for its expression.

Keywords: zooarchaeology; agriculture; urbanisation; connectivity; economy; Republican Rome; Etruscan

\section{Introduction}

During the Neolithic, the diet of ancient Italian communities became based on four key species: domestic cattle, sheep, goat, and pig. The remains of these animals are one of the most common materials recovered from archaeological sites, and the food systems evidenced by them are of central importance to understanding socio-economic change in antiquity. Such change is particularly relevant to protohistoric and early Roman Italy, a period of urbanisation and dynamic social transformation (Smith 1996; Riva 2010; Terrenato 2019), alongside an expansion of production and exchange (Nijboer 1998; Morel 2007; Becker 2017; Roselaar 2017). Agriculture was not excluded from this re-organisation of the natural and social landscape. From the late seventh century $\mathrm{BC}$, increasing numbers of small settlements and construction of hydraulic works in the hinterland of urban centres demonstrate an intensification of agricultural production and natural resource exploitation (Cifani 2002; de Haas 2017; Zifferero 2017), and archaeological remains attest to increasing investment in, and the commercialisation of, agricultural products (Barker 1988; Bergamini 1991; Perkins 2012). Within this context, animal management also evolved.

Despite the interconnected nature of agricultural production, resource control, and wealth accumulation, the relationship between animal husbandry and socio-economic change in protohistoric Italy is not often discussed with the same zeal as other material types. Architecture, grave goods, and amphorae have received much more attention than organic remains in charting cultural transformations. The dialogue between form, function, social ambitions, and practical constraints is broadly accepted as a force that shapes architecture 
and material culture; these material types have been central to the investigation of economic development, social stratification, and cultural transformations during this period (e.g. Izzet 2007; Riva 2010; Potts 2015). In contrast, animals are typically held to be passive receipts of human action, more useful in reconstructions of subsistence strategies than social change. Perhaps this is because the cast of characters is rather staid, with the familiar refrain of 'cattle, sheep, goat, and pig', occasionally punctuated by a few red deer, perhaps a wild boar, or - more rarely - a cameo appearance from an exotic animal. However, livestock management provides evidence of human as well as animal lives. Environmental tolerance or resource availability can promote or preclude certain farming and consumption practices (e.g. Redding 2015), but social forces were of central importance to decisions on livestock husbandry (Crabtree 1990; deFrance 2009). Agriculture was the driving economic force in ancient Italy, and most of the population was dedicated to farming. Every community was highly skilled in animal management, since failure in agriculture meant not just lost man-hours, but potential starvation. The skills employed in raising animals were also highly local, tailored not only to the surrounding environment, but also cultural traditions, social structure, and economic scale.

This paper focuses on the central and northern parts of Italy (Etruria, Etruria Padana, and Latium: Figure 1), an area inhabited by several protohistoric cultures. Amongst these, the Etruscans are perhaps

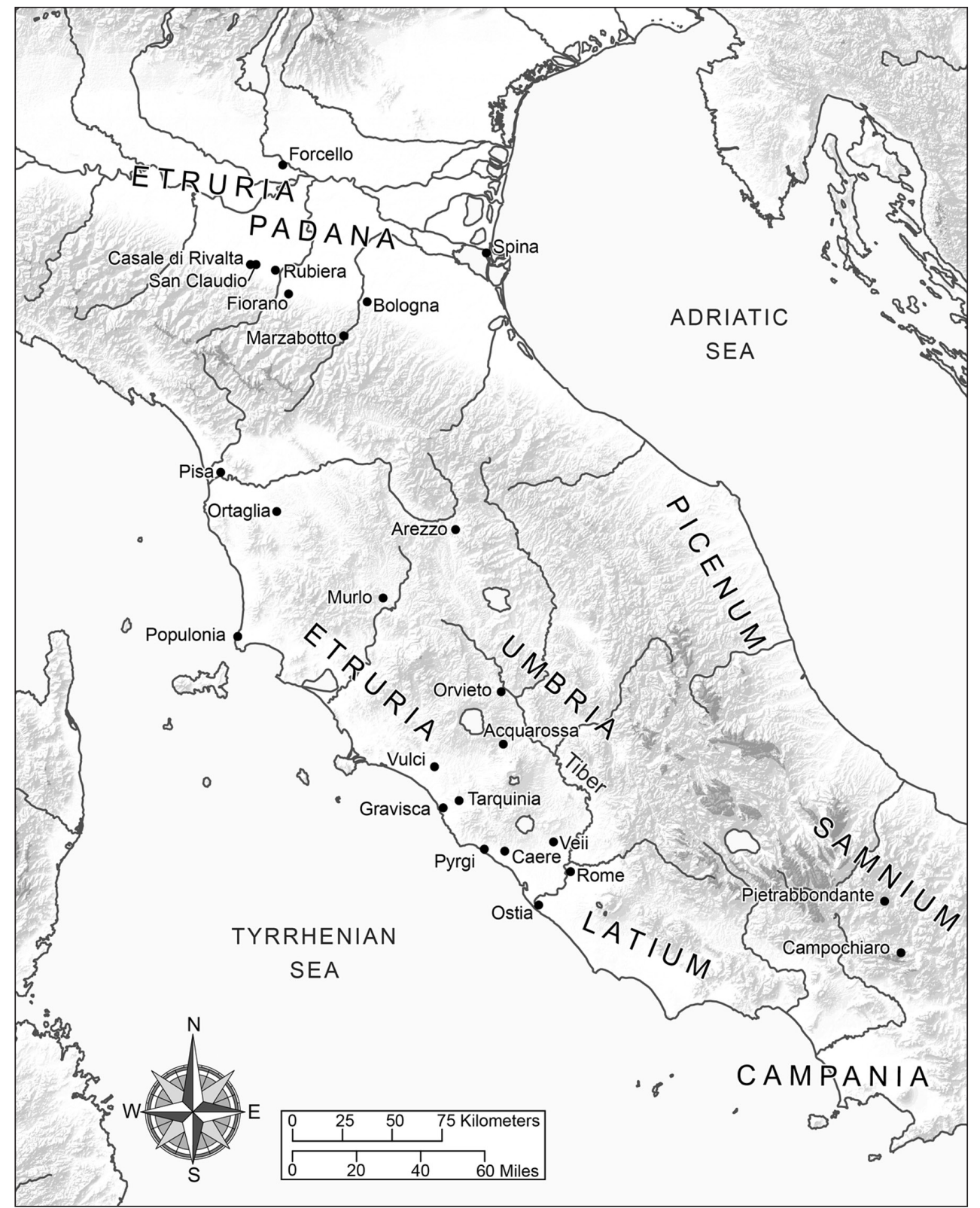

Figure 1: Map of central and northern Italy during the mid-first millennium BC with major sites and those sites mentioned in the text (Adapted from Ancient World Mapping Center map of 'Northern Italy'). 
most renowned, on account of their monumental tombs and written language, alongside Roman and Latial culture south of the Tiber River, and other linguistically distinct peoples to the north and east. Decades of excavation have produced a corpus of animal bone assemblages that allows us to reconstruct not only ancient diet, but also changing aims of animal management. The zooarchaeology of protohistoric Italy was first considered in the 1970s and 1980s by Barker (1976; 1989), De Grossi Mazzorin (1985, 1989), and Riedel (1978; 1988). Since then, scholars have been able to refine regional variation and the chronological scale of trends in northern (e.g. Riedel 1994; Trentacoste 2016; Trentacoste et al. 2018 and references therein), central (De Grossi Mazzorin and Minniti 2009; Minniti 2012a), and southern areas of the peninsula (de Grossi Mazzorin and Minniti 2019b), including the city of Rome itself(De Grossi Mazzorin and Minniti 2017). Amongst identified trends, three key patterns emerge over the first millennium BC: pigs became more abundant; cattle, sheep, and goats (but not pigs) increased in size; and the production of sheep/goat (which are difficult to distinguish in the archaeological record) shifted to emphasize secondary products (wool, and possibly milk) and young lamb. Other important adaptations include the introduction of chicken as a form of livestock, and the development of new 'breeds' or animal types with desirable characteristics. This paper aims to tap into the more elusive facets of animal use, and to demonstrate how those ever-present 'cattle, sheep/goat, and pig' participated in the broader transformations which characterise protohistoric and early Roman Italy. Viewed as a part of broader socio-economic developments over the course of the first millennium BC, animals become active players in sustaining new commercial and social ambitions, shaped alongside other forms of culture by communities into new forms and products that fed not only physical hunger, but social ambition as well.

\section{Pigs for the People}

The expansion of pig husbandry over the first millennium BC is one of the most widely recognised zooarchaeological trends in Italian antiquity, on account of its longevity and continued association with Roman culture. Over this period, we find a dramatic increase in the percentage of pig remains recovered from archaeological sites (MacKinnon 2004; De Grossi and Minniti 2009; 2017; Minniti 2012a; Trentacoste 2016). This trend is apparent in both north and central Italy (Figure 2), and it appears to emerge in Rome and Bologna (Farello 1995; Minniti 2012a) around the eighth century BC. The abundance of pig bones continued to climb into the Roman Imperial period, when pigs represent over $60-70 \%$ of remains on many sites in central Italy (MacKinnon 2004; De Grossi and Minniti 2009; 2017). The link between pigs and central Italy is so pronounced that increased pork consumption in the Roman provinces is frequently viewed as the 'Romanisation' of local foodways (e.g. King 1999; MacKinnon 2010b; Valenzuela-Lamas and Albarella 2017a). The central role of pork in Rome's diet was even institutionalized in the third century AD, with its addition to the annona food distributions alongside bread, salt, and wine (Mattingly and Aldrete 2000).

The increase in pig consumption in protohistoric Italy is typically viewed as a response to population growth and the increased demand for meat, particularly amongst urban populations (see De Grossi Mazzorin and Minniti 2017 and references therein). The marked abundance of pigs remains found in Etruscan towns and cities, compared to rural sites, supports this hypothesis (Farello 1995). However, significant percentages of pig bones are not limited to urban settlements, and many sanctuaries and cultic deposits contain

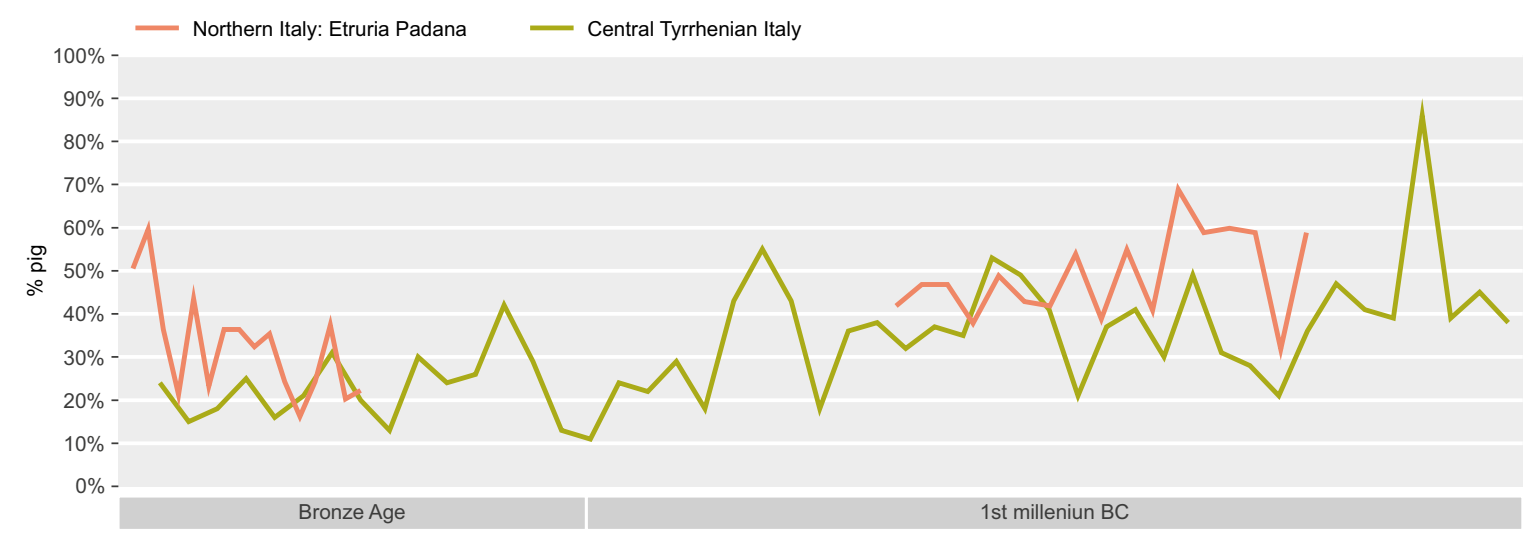

Figure 2: Proportion of pigs amongst the number of identified specimens (NISP) of the three main domesticates (cattle, sheep/goat, pig) from sites in northern and central Italy. Only includes assemblages with livestock NISP > 100. (See Supplementary Table 1 for data. Source: Author). 
a pronounced abundance of one taxon. The ternary plot in Figure 3 depicts the relative percentages of the three main livestock taxa in different assemblages. Ritual assemblages plot towards the corners of the graph, illustrating that one taxon was significantly more abundant than the other two. In central Italy, the preferred taxon is generally pig. However, in these ritual assemblages, high frequencies of pigs allude to the location's social and economic roles, rather than reflecting population size (Trentacoste 2016). Although very different in form and dimensions, cities and sanctuaries had a shared function, as central nodes in trade/exchange networks, as well as fora for the display of wealth and social status (Frayn 1993; Nijboer 2004; Becker 2009; Potts 2015; Biella 2019). In many parts of Italy, pigs were the easiest form of livestock to produce in abundance with minimal effort, and thus a moveable form of surplus agricultural wealth that could be distributed as needed.

This productive strategy would require animal mobility, and movement of livestock from off-site locations to centres of consumption. Looking at ancient Samnite sites, Barker (1989) noted differences in species representation and livestock exploitation patterns at sanctuaries compared to settlements, which he attributed to the movement of animals from the hinterland to ritual sites. Animal bone assemblages from sanctuaries, particularly those at Campochiaro and Pietrabbondante, contained a notable abundance of pig remains - markedly higher proportions than on the farms and villages considered. Furthermore, the sanctuary at Pietrabbondante also produced evidence of young, prime beef cattle. Considering that pigs are the animal most mentioned in references to Samnite sacrifice, Barker (1989) hypothesised that sancuatries functioned as central places that received animals from the hinterland for rituals conducted by leading families (Figure 4). Barker was unable to find similar zooarchaeological evidence for it in Etruria at the time, but updating this investigation with recent data suggests that similar patterns of livestock mobility existed across proto-historic Italy. While modern pigs are not very mobile, most Roman pigs were probably reared off-site, in order to take advantage of pannage in local woodlands (MacKinnon 2001). Extensive pig management is attested in historical sources (Dionysius Halicarnassensis, Antiquitates Romanae 3.70; Polybius 2.15; Strabo 5.1.12), and it was common in the Mediterranean until recently (Albarella et al. 2011; Halstead and Isaakidou 2011; Wealleans 2013). Recent analysis of suid bones from the Archaic town of Forcello in the Po Plain has demonstrated that the pigs consumed acorns and were herbivorous, strongly suggesting off-site management in the local woodland (see Alldritt et al. 2019; McCullagh, Hedges, et al. in prep.). Similarly, stable isotopes from Roman pig bones indicate that pigs in Imperial Italy were also generally herbivorous, similar to sheep and cattle, rather than omnivorous like dogs or humans (see Trentacoste et al. 2020). These results suggest that many pigs were not stall-fed on table scraps or human food waste, but instead grazed in out-of-town environments. Extensively raised pigs could then be driven to a central

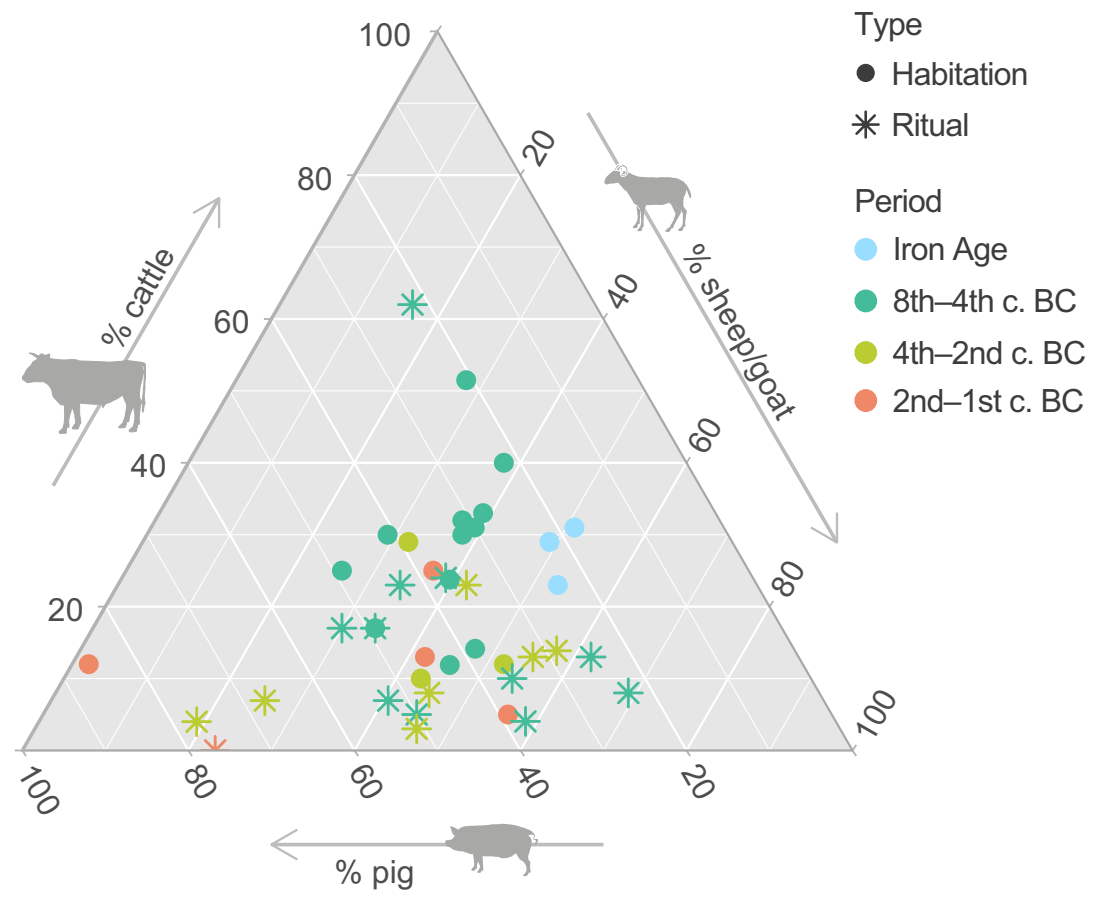

Figure 3: Relative abundance of main domesticates on ritual and non-ritual sites in central Italy. Only includes assemblages with livestock NISP > 100. (See Supplementary Table 2 for data. Source: Author). 


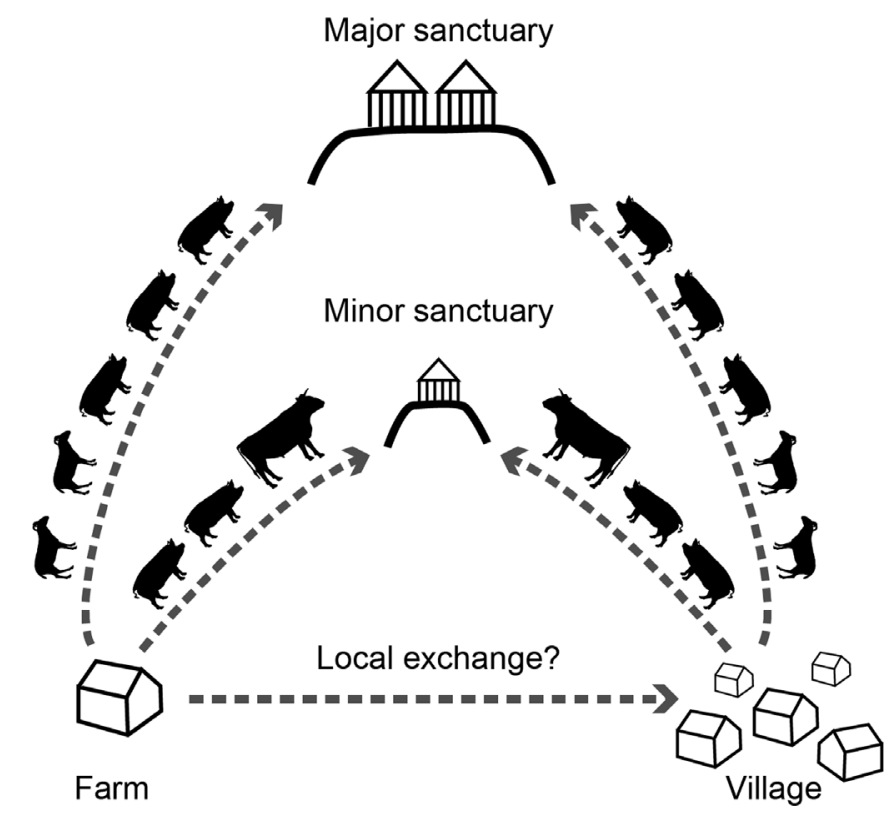

Figure 4: Simplified model of the movement of surplus animals in protohistoric Italy. (After Barker 1989: Figure 3).

place for slaughter. Such models have already been proposed for Iron Age France (Frémondeau et al. 2017); similar scenarios are possible for Italy.

Surplus pig production brought several benefits. Surplus animals could be used to provision traders, create cured products for market, pay debts or tribute, and incur divine favour (or social standing) through sacrifice (Trentacoste 2016). Pigs are often abundant in the same places as early economic centralisation (see Nijboer 2004; 2017b; Morel 2007; Biella 2019): sanctuaries, cities, and long-distance trade hubs. A shipment of over 500 pig scapulae from a second-century BC shipwreck at Pisa illustrates the bulk transport of pork shoulders, presumably pickled or cured (Sorrentino et al. 2000); trade or bulk processing may also explain the notable abundance of this bone in the Etruscan port-town of Forcello (Trentacoste 2014). The very high percentage of pigs at Republican Ostia (87\%: the highest point in Figure 2 and outlying habitation assemblage in Figure 3) would also be linked to special types of provisioning at a major exchange node. High proportions of pig bones in central places suggest these animals were mobilised from the surrounding hinterland, as has been documented for sheep in Etruscan Orvieto (Trentacoste et al. 2020) and pigs in France at Iron Age Leroux (Frémondeau et al. 2017). Etruscan inscriptions document the involvement of particular families in certain religious rites and sacrifices (Jannot 2005: 81-82). Such families may also have supplied the animal victims: a service which would serve to highlight not only the piety of the providers, but their wealth as well (Rives 2019). By the Roman period, such euergetism was common, and it served to curry divine favour and cement the social and political roles of local elites (Petropoulou 2008; Rives 2019). In this context, protohistoric pigs not only provided meat for the urban masses, but they also sustained trade, facilitated the creation and redistribution of agricultural wealth, and provided a means for costly display. Population size and density were not the sole drivers of pig consumption, but marketisation, connectivity, and a site's relative role in transforming agricultural surplus into other forms of wealth and social capital were aspects that shaped animal use.

\section{Cattle: Evidence for Improvement}

Across Western Europe, cattle increased significantly in size after Roman conquest (Valenzuela-Lamas and Albarella 2017b and papers therein). This increase in the size of livestock broke from millennia of progressive size diminution which began in the Neolithic. It represents a significant change in how animals were managed, at least until Late Antiquity, when cattle stature again decreased (e.g. Frémondeau et al. 2017; Rizzetto et al. 2017). Although there is evidence from France indicating an increase in cattle size from the second century BC (Frémondeau et al. 2017; Duval 2018), in Italy this increase is visible centuries earlier (Riedel 1994; De Grossi Mazzorin 1995; Trentacoste et al. 2018; De Grossi Mazzorin and Minniti 2019b). These trends were fully developed by the Archaic period in the mid-first millennium BC, although earlier incremental changes suggest development from as early as the Bronze to Iron Age transition (Trentacoste et al. 2018; De Grossi Mazzorin and Minniti 2017; 2019b). 
In both northern and central Italy, cattle increased in size despite a wider trend toward diminution in other parts of Europe during the early Iron Age. Rather than a universal, external catalyst (like climate change), livestock improvement in Italy must have been driven by new changes to animal management strategies. Although statistically significant increases in cattle size are visible across urban and non-urban communities (Trentacoste et al. 2018), the distribution of the data suggests that urban centres had a key role in mediating access to larger, desirable animals. Using the Log Standard Index (LSI) technique (Meadow 1999) to compare cattle post-cranial measurements, differences emerge between northern Italian site types (Figure 5). LSI values scale measurements to a standard, in this case a cow from Catalonia (Nieto-Espinet 2018), and the resultant values indicate the degree to which the considered measurement is larger (positive LSI value) or smaller (negative LS value) than the standard. This technique allows measurements to be pooled, rather than relying on total lengths from unbroken limb bones, which are typically rare in archaeological assemblages. Major Etruscan sites (towns and cities, e.g. Bologna, Marzabotto, Spina, Forcello) contain larger cattle than minor Etruscan settlements (farms, villages). Cattle on major sites are, on average, both taller and more robust than cattle on rural sites, and the largest animals overall are also found on major sites. Non-Etruscan settlements from the region north of the River Po have cattle smaller on average than either Etruscan group, although a few large individuals are present. This distribution of cattle reinforces site hierarchies, and suggests greater selection for large animals in urban sites, the transport of the largest animals from the hinterland to major centres, or greater preference for male cattle. Further research into site-specific age and sex profiles is needed to understand whether urban/rural differences represent bulls, oxen, or phenotypically larger livestock of either sex, but regardless of their origin, urban Etruscan sites had greater success creating or attracting large cattle.

One reason that could prioritise a size increase in cattle was the need for muscle power. In Etruscan Italy, cattle were predominantly slaughtered in late adulthood, and lower limb pathologies evidence their use for traction (Trentacoste 2016). Stronger animals could work harder and exploit heavier soils, increasing the production of cereals required to feed urban centres. Later Roman agronomists explicitly state the importance of size and working capacity, as well as colour, as a marker of different cattle types (e.g. Columella, De re rustica 6.1.1-3; Varro, De re rustica 2.5.6-11; see MacKinnon 2010a). However, if big cattle were developed for agricultural labour, why are the largest animals in towns and cities? One explanation is that they were sent there for slaughter after working lives further afield, or that cities were able to maintain the largest stock to work their own environs. Alternatively, a cultural preference for large animals, especially those of a specific sex, conformation, or colour, could also drive these patterns. In protohistoric Italy, practically every aspect of material culture could be used to articulate identity, and inter-elite competition played out everywhere from temples to tombs (Izzet 2007; Riva 2010; Potts 2015). Cities were centres for this type of display,
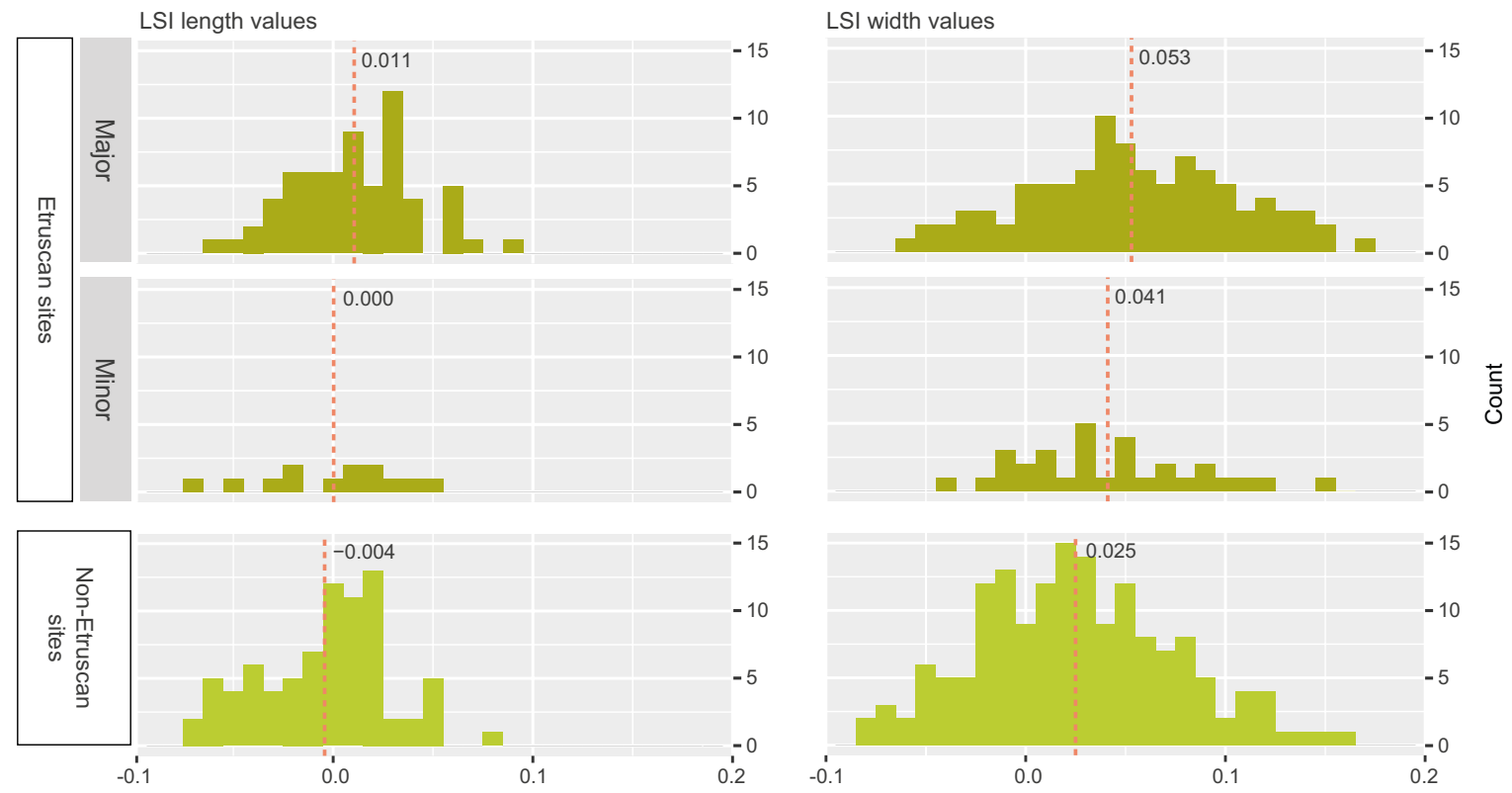

Figure 5: Histograms of Log Standard Index (LSI) values from cattle post-cranial bones recovered from sites in Northern Italy. (See Supplementary Table 3 for site list. Data from Trentacoste et al. 2018. Source: Author). 
and the animal pulling an ornate chariot or presented at a public sacrifice would have been as important as the more archaeologically durable elements of these scenarios. Roman rituals called for male or female cattle of with specific colours (Dumézil 1987: 550-551; Scheid 2007), and Varro notes that certain breeds of Italian cattle were preferred as sacrifices, on account of their size and white colour (Rust. 2.5.10-11). Virgil also refers to the use of white Italian cattle in triumphs and sacrifices, which might be marked from birth for such purposes (Georgics 2.145-148; 3.156-165). The ability to furnish one of the most costly and least common forms of livestock (bulls) in the rarest of colours (white), and then kill it, demonstrates an immense quantity of disposable wealth. In this context, cattle not only offered power to pull ploughs, but a means of expressing wealth, resource access, and influence: political and social as well as physical power.

\section{Sheep: Specialisation of Animals and Materials}

Specialised livestock husbandry during the later prehistory had a significant impact on the formation of sheep 'breeds' as noted by Roman authors. Sheep in northern Italy and Puglia were renowned for their fleeces, and sheep varied in colour across the peninsula (e.g. Columella, Rust. 7.2.3-7.3.2; Pliny, Naturalis historia 8.190-191; Strabo, 5.1.12). Sheep 'landraces' also differed in size and shape, with taller animals in the lowlands and shorter varieties in the mountains (Columella, Rust. 7.2.3). Regional diversity and various 'landraces' also existed in prehistory, but the change from household to workshop and more industrial scales of production supported formation of specialized herds and even types of sheep. Textiles were major sources of wealth and prestige in protohistoric Italy, and wool was one of the most important raw materials in their production (Gleba 2008). Written, iconographic, and archaeological sources document the sumptuous garments worn by the elite, who distinguished themselves and displayed their wealth through the use of rare dyes, gold thread and appliques, elaborate woven designs, and even three-dimensional pleating (Gleba 2017a). Considering the amount of wealth and craftsmanship dedicated to these prestige textiles, it is not surprising to find that their production also had an important social role. Textile tools have been recovered in large numbers from tombs, domestic contexts, and even sanctuaries, where they provide an important testament to the ubiquity and social importance of this activity (Meyers 2013).

The final quality of a finished textile depends on that of the raw material, and recent analysis of preserved textile fragments shows that several fleece qualities coexisted in Italy by the end of first millennium BC (Gleba 2012). The appearance of homogenous, fine fleeces in the later part of this period suggests that breeders were actively improving sheep for wool quality. The method of collection also appears to have changed over later prehistory. Shears came into use during the Iron Age, signalling a transformation in the collection of wool (Ryder 1992; Rast-Eicher and Bender Jørgensen 2013). This shift from plucking to cutting demonstrates the development of non-shedding fleece, allowing for removal at a chosen time and place. Sheep were also selected based on colour. Primitive European breeds are typically brown, while white wool would be needed to create bright white or vibrantly coloured garments. White fleeces were preferred in the Roman period precisely because they could be dyed (Columella, Rust. 7.2.3). However, even during the Imperial period pure white animals could not be produced without continued effort. As Columella notes, a 'dark lamb is often the offspring of a white ram' (7.2.5). Careful inspection and selection of breeding animals were therefore required in order to continue to produce white sheep (Columella, Rust. 7.2.5; Varro, Rust. 2.2.4), suggesting that white animals were not ubiquitous, even when Varro was writing in the first century $\mathrm{AD}$. These improvements in the raw material needed for textile production mirrors developments in the production process. Textile tools became smaller and more standardized during the first millennium BC, suggesting the creation of finer products and greater expertise (Gleba 2008).

On account of their distinct textile tradition, Greek colonisation of southern Italy would have introduced further selective pressures. The textile fragments that survive from Iron Age and Etruscan contexts show that central Italian communities wore highly decorated fabrics that shared many characteristics with Hallstatt examples from central Europe (Gleba 2017b). In contrast, the Greek textiles were 'technically, aesthetically and conceptually different' (Gleba 2017b: 1219). Although both cultures used wool, Greek textiles were produced using distinct methods that resulted in considerably finer cloth with higher thread counts per centimetre. Sheep with fleeces of the colour and fineness needed to produce Greek-style fabrics were not necessarily present in southern Italy. Based on a size increase in southern Italian sheep, Gaastra (2014) has suggested that Greek communities were indeed importing sheep or improving local animals. If Greek colonisation contributed to southern Italian 'breeds', it would explain why some southern Italian varieties are described in Roman sources as 'Greek' or 'Tarantine' (Frayn 1984: 34). According to Pliny (HN 8.73), the wool of these sheep was valued above all others, and it held significant commercial value as a result. However, more recent work has demonstrated that a size change in sheep was not unique to Magna Grecia, and 
an incremental increase in the body of sheep pre-dating Greek contact has been documented throughout central and northern areas of the peninsula (Trentacoste et al. 2018; De Grossi and Minniti 2019b). Greek colonisation may have contributed to this process by facilitating access to new types of sheep, but it did not catalyse the broader re-organisation of animal management suggested by the increase in sheep body size. Although a motive for shipping sheep existed in southern Italy, archaeologically identification of the practice will require bioarchaeological investigation through isotopes or aDNA.

For the industries dependent on sheep and their raw materials to expand beyond household production, livestock husbandry also must have shifted to a larger, surplus-oriented economy supported by significant investment. Over the first millennium BC, sheep production intensified and became increasingly concerned with valuable, marketable products like fine white wool. New varieties of sheep emerged, as the animals themselves were shaped to specific tasks, contributing to the types of animal documented by Roman authors. These changes demonstrate an increase in investment and selective breeding, the latter made possible by an expansion of herd size and/or economic integration. Further evidence of these practices is provided by biometric data, which demonstrates an increase in sheep size across Italy over the first millennium BC, perhaps beginning as early as the late Bronze Age (De Grossi Mazzorin and Minniti 2017, 2019b; Trentacoste et al. 2018). As in cattle, this size increase constituted a break from a long-established trajectory of size diminution. Whether the result of a better management or foddering practices, more selective breeding, or the introduction of larger varieties of sheep, or a combination of these factors, this increase in body size illustrates the application of new management strategies and a greater input of resources and/or labour compared to previous periods. These changes shaped new types of sheep that are archaeologically visible in the development of wool and animal biometry.

\section{Chicken: Exotic Animal, Adopted and Adapted}

The final domesticate considered here is the chicken, a bird introduced to Italy during the Iron Age (Figure 6). The earliest chicken bones in Italy derive from funerary contexts. The oldest dates to a tenth century BC tomb at Castel Gandolfo Albarella and Corbino in prep. (following the high chronology for the Latial IIA, see Guidi 2018), followed by several Villanovan tombs in Bologna's Benacci-Caprara necropolis (see De Grossi Mazzorin 2004; 2005). By the Archaic period, the birds had become more common, and several settlements in northern Italy dated to between the sixth and fourth centuries BC have produced chicken bones (e.g. Forcello, Casale di Rivalta, San Claudio) (see Trentacoste 2014). Their numbers also increased in central Italy, but here they only derive from areas with a funerary, ritual, or symbolic character, rather than domestic rubbish. Examples include bones from the Pian di Civita of Tarquinia (Bedini 1997), the sanctuary at Ortaglia (Bruni 2005), and a semi-subterranean shrine at Caere (Colivicchi et al. 2016). The continued association between domestic fowl and the funerary sphere is demonstrated by painted depictions of chickens in tombs at Tarquinia, like the Tomb of the Triclinium (c. $470 \mathrm{BC}$ ), the Tomb of the Little Flowers (second quarter of the fifth century BC), and the Tomb of the Warrior (first half of the fourth century BC) (Steingräber 2006). Only after the fifth century BC did chickens appear in non-ritual habitation contexts in central Italy, and their diffusion into the everyday, quotidian sphere accelerated from this point. Hundreds of chicken bones recovered from the fill of a cunicolo at Centocelle (Rome) provide the earliest testament to chicken husbandry on a significant scale (De Grossi Mazzorin 2004). While this deposit was interpreted as having a cultic origin, the presence of over 70 individuals ranging in age from hatchlings to adults suggests the presence of a breeding population in the vicinity between the late fourth and early third century BC. By the Roman period chickens had become common part of urban and rural life throughout the peninsula (De Grossi Mazzorin 2005; De Grossi Mazzorin and Minniti 2009; 2019a; Corbino et al. 2017; in prep.). Domestic fowl typically represent between 5-8\% of animal bones recovered from sites around the Bay of Naples and are commonly found in assemblages from Ostia (MacKinnon 2014) and Rome (De Grossi Mazzorin 2005), as well as in Northern Italy (e.g. Wilkens 1997).

The timing of the appearance of chickens in different contexts offers clues on the nature of their adoption. The birds first appear in the funerary record, and in central Italy they are restricted to this sphere and areas with a ritual character for a few hundred years after their initial appearance. As an exotic bird with fantastic plumage (at least on males), chickens were probably first introduced as luxury goods in the form of rare pets, or as fighting birds, as evidenced by scenes of cock fighting in tomb art. Their appearance under sumptuous banqueting couches in Etruscan funerary art reinforces their status as exclusive animals, as well as their exotic roots. The Etruscan banqueting scenes that depict these birds share iconographic and formal similarities with contemporary, if not slightly earlier, paintings from the eastern Mediterranean 


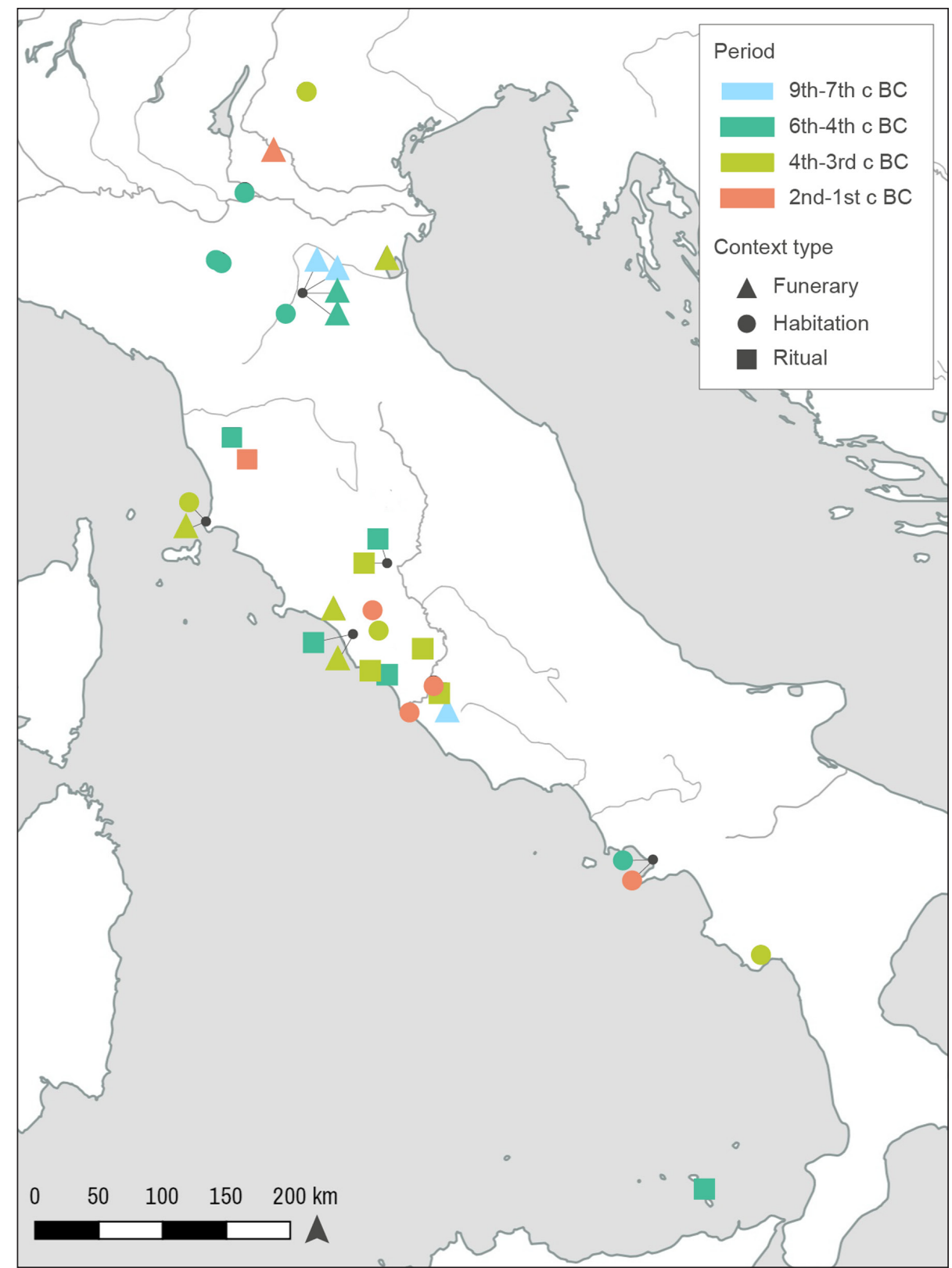

Figure 6: Map of first millennium BC sites with chicken remains. (See Supplementary Table 4 for details. Source: Author).

(Figure 7) (Steingräber 2010): Karaburun tomb II in Lycia on the southern coast of Turkey (c. 475 BC) (Mellink 1974; Miller 2010), and a Klazomenian sarcophagus from Akanthos (c. 500-470 BC) (Kaltsas 19961997). In both the eastern examples, cockerels are depicted beneath the klinai couches of reclining diners, alongside a dog and a partridge, exactly as depicted at Tarquinia in the Tomb of the Triclinium (Figure $\mathbf{7 b}$ ). Another similar example is found on a funerary stele recovered from near Arezzo (Florence, Museo Archeologico Nazionale, inv. 89539) (Figure 7c). Although four wild Galliformes are endemic to peninsular Italy outside of the Alps (three species of partridge - Alectoris graeca, Alectoris rufa, Perdix perdix - and the common quail - Coturnix coturnix), their remains are unknown on central Italian sites of the period. The three wild Galliforme bones from the Po Plain warrant re-identification: a pheasant at San Claudio (Farello 1990), a bird not indigenous to Italy; a small Galliforme from Fiorano Modenese (Farello 1989a), described as 'maybe a quail'; and a Perdix perdix specimen from Rubiera (Farello 1989b). Based on the zooarchaeological evidence, partridges appear to have been extremely rare, if not absent, on Italian sites in these areas. Thus the banquet scenes attended by a dog, partridge, and cock within an Etruscan tomb suggest that this depiction of a chicken should be read more in relation to the trappings of pan-Mediterranean aristocratic culture, rather than a bucolic rural scene. 
a

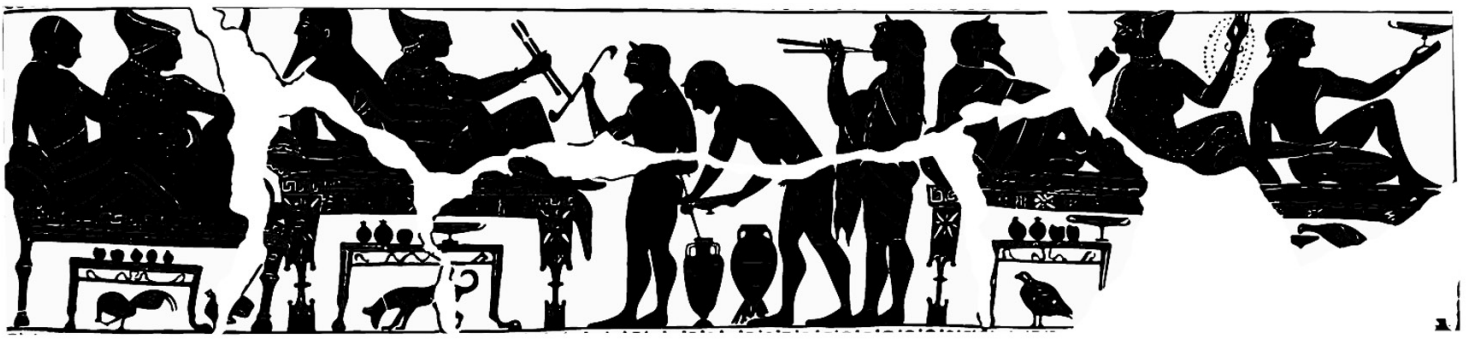

b.

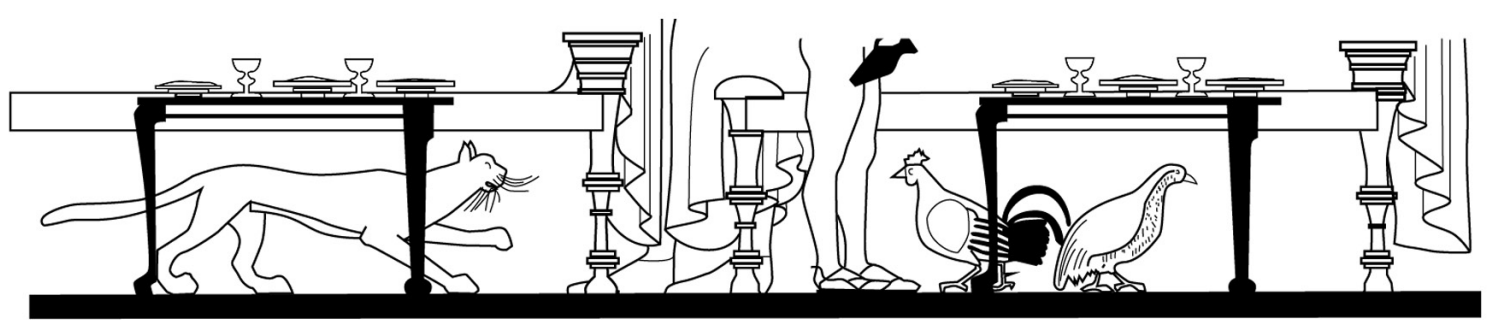

c.
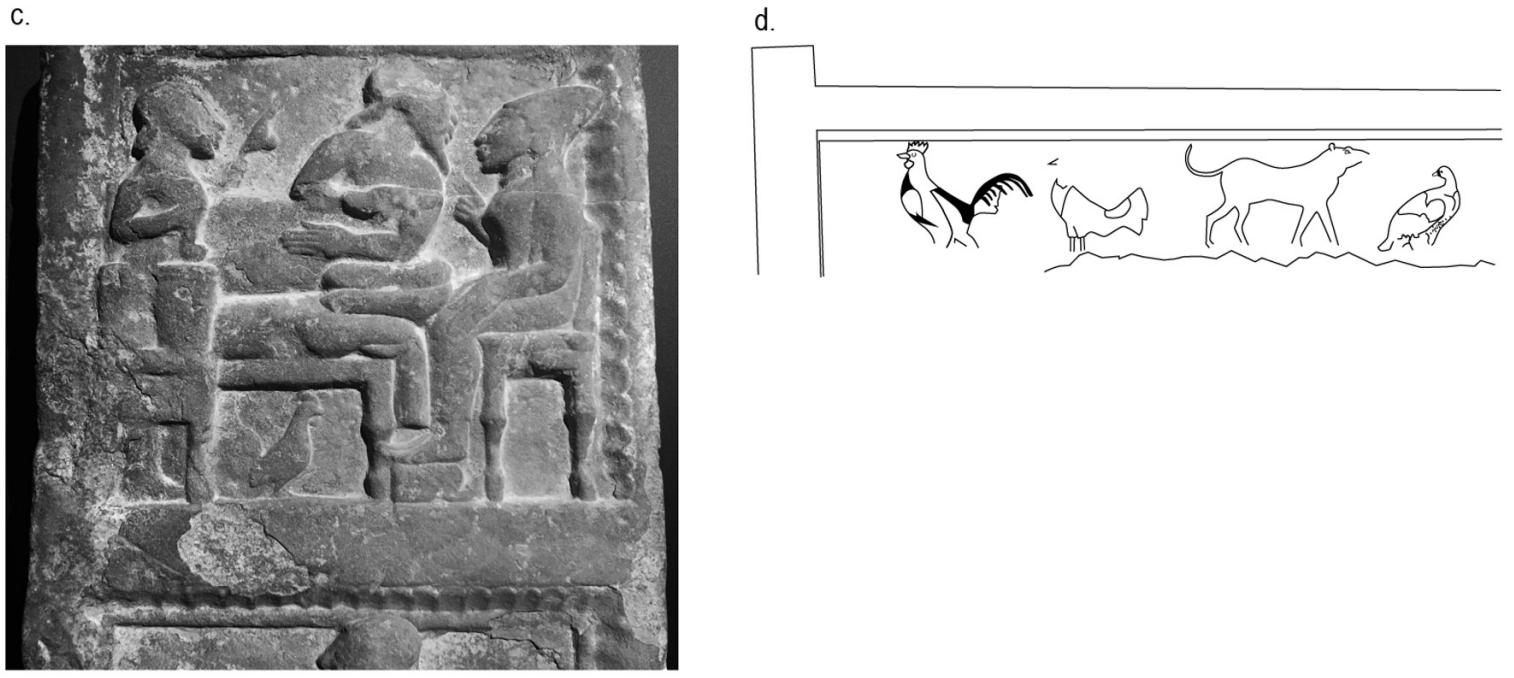

Figure 7: Chickens in Mediterranean funerary art: a) Klazomenian sarcophagus, Akanthos, Greece (c. 500-470 BC); b) Wall painting, Tomb of the Triclinium, Tarquinia, Italy (c. 470 BC); c) Stone stele, Arezzo, Italy (late sixth century BC); d) Wall painting, Karaburun tomb II, Turkey (c. 475 BC). (See text for references. Source: Author).

Before chickens became a common motif in tomb art, there were eggs. Eggs are frequently found in early Iron Age tombs, often placed in ceramic tablewares deposited with the deceased (Bertani 1995; de Grossi Mazzorin and Minniti 2009; Minniti 2012b). This symbolism is picked up in later Etruscan tomb paintings, where eggs are held in the outstretched hands of diners in depictions of funerary banquets (Pieraccini 2014). Although some of these eggs may be from other birds, ducks (the most likely alternative) are not thought to have been domesticated until the Roman period (Albarella 2005), and domestic chickens would have produced more eggs than wild fowl. If eggs were already a potent symbol, as well as a valuable food source, did an interest in eggs encourage the adoption of chicken husbandry? Or offer an existing symbolic framework into which chickens neatly fit? These questions may remain open, but judging by the timing of chickens and eggs in Etruscan tombs, we can answer the age-old question: at least in this content, the symbolic chicken came after the symbolic egg.

Artistic representations of domestic fowl and the restriction of chicken bones to funerary and ritual contexts (in central Italy) until the late first millennium BC suggest these exotic birds arrived in central Italy as part of a wider package of elite artistic and social practices adopted from the eastern Mediterranean during the Orientalizing and Archaic periods. However, chickens in northern Italy seem to have lost their exclusivity by the sixth century $\mathrm{BC}$, when they are found mixed with common rubbish in towns and on farms. Could 
the different character of northern and central Italian chicken exploitation suggest more than one route of introduction for these birds? A re-analysis of Galliforme bones from the Czech Republic placed the earliest chickens there in the ninth century BC; here again the bones were recovered from a grave (Kyselý 2010). There are a few finds of chicken bones from Greece and Crete dated to the late second millennium BC, but these examples are probably intrusive; the earliest securely dated Iron Age chicken bone in Greene is from fifth-century BC Athens (Dibble 2017). Based on find spots and iconography, Etruscan central Italy with its trade orientation towards the eastern Mediterranean, seems to have adopted chicken from sea-links, but the different character of finds in northern Italy may suggest a second route oriented towards the Balkans or maritime trade in the Adriatic. Whatever the motivation behind their introduction and diffusion, by the last centuries of the first millennium BC chicken had become a common domestic species throughout Italy, and domestic fowl made a significant contribution to diet the Roman period, especially in urban areas. However, chickens never entirely lost their ritual value. During the Imperial period, cocks were sacrificed to the household gods and depicted on domestic altars (Boyce 1937; Toynbee 1973: 273). Roman mithraea have yielded huge deposits of chicken bones, consumed during cult meals (Lentacker et al. 2004).

Just as artistic motifs, architectural techniques, and urban forms were adopted and adapted (Izzet 2007), so too were animals deliberately integrated into Italian communities. Domestic fowl offered functional advantages to food production in the form of eggs and meat, particularly in urban contexts where space was limited. However, their early adoption was driven more by social ambition than subsistence concerns, just like the elegant banqueting equipment with which they are pictured. An existing interest in eggs as a symbol and food source may have encouraged the introduction of chickens, but their ability to articulate access to pan-Mediterranean trade networks was equally as important, at least in central Italy. As scales of production increased, the birds eventually lost their exclusivity, just like roof tiles, metal objects, and other items with restricted distributions during the sixth century BC, later came to abound on Roman sites.

\section{Conclusion}

Over the first millennium BC, communities in Italy adapted their use of cattle, sheep, pigs, and chickens in the face of new economic, social, and political challenges. As a result, livestock were at the forefront of changes to the productive landscape. Population growth drove the demand for animals and animal products, and livestock husbandry adapted in response. Animal production became increasingly concerned with marketable products, which in turn became more widely available. The expansion and intensification of trade networks throughout later prehistory introduced communities to new raw materials and animal types. These networks encouraged the exchange of live animals, driven by desire for particular characteristics like colour or size. New and more specialised livestock types emerged, as the animals themselves were shaped to specific tasks. Chickens, both a curiosity and new productive technology, were adopted as exotic, symbolic animals, before undergoing a transformation into quotidian poultry, as their use migrated from the religious to the domestic sphere. Urban, rural, and religious communities had different roles in this transformation of the productive landscape, suggesting a complex food system increasingly concerned with surplus production. Like urban plans, architectural forms, and textile culture, domestic livestock were actively moved and shaped to serve the ambitions of protohistoric societies. Considering the sophistication demonstrated by comparatively marginal forms of animal production like bee-keeping (Castellano et al. 2017), alongside the extensive knowledge demonstrated by Roman authors at the end of the first millennium BC (MacKinnon 2004), it is difficult to conceive protohistoric livestock management as anything other than a sophisticated and organised activity - even if the local aims of production differed between regions and communities.

In light of the broader archaeological evidence for the intensification of industrial activities and the move toward a market economy over the first millennium BC (Nijboer 2004; 2017a; 2017b; Morel 2007), it is not surprising that agricultural production - a primary source of wealth - was brought to serve the same interests as other material types. Livestock offered not only an inheritable investment, but a means of creating new wealth through surplus food production, creation of raw materials, and harnessing greater animal power. Animals were used to demonstrate this wealth, as well as the control over resources and social connections required to sustain it. Changes to livestock management were the cause as much as the consequence of these socio-economic developments, and not simply the functional outcome of urbanisation. Rather than resulting from major technological innovations, these transformations of the productive landscape reflect a change in the decision-making of communities, which participated in, or abstained from, new markets and social structures. As in the transformation of other forms of material culture during this period, livestock husbandry regimes were not simply the deterministic result of wider socio-economic change, but a medium shaped for its expression. 


\section{Additional Files}

The additional files for this article can be found as follows:

- Supplementary Table 1. Site list and taxonomic data used in Figure 1: Livestock representation in assemblages from central and northern Italy with NISP > 100. DOI: https://doi.org/10.16995/ traj.414.s 1

- Supplementary Table 2. Site list and taxonomic data used in Figure 2: Livestock representation in central Italian ritual and non-ritual assemblages with NISP > 100. DOI: https://doi.org/10.16995/ traj.414.s2

- Supplementary Table 3. Site list used in Figure 3: Etruscan and non-Etruscan sites in northern Italy with biometric data for cattle. DOI: https://doi.org/10.16995/traj.414.s3

- Supplementary Table 4. Site list used in Figure 4: Italian sites with chicken remains. DOI: https:// doi.org/10.16995/traj.414.s4

\section{Acknowledgements}

This research was supported by a Mougins Museum Rome Award at the British School at Rome (2014), Etruscan Foundation Research Fellowship (2014), and the ERC-Starting Grant ZooMWest - Zooarchaeology and Mobility in the Western Mediterranean: Husbandry production from the Late Bronze Age to the Late Antiquity (award number 716298), funded by the European Research Council Executive Agency (ERCEA). I am grateful to L. Lodwick for helpful comments on a draft of this paper.

\section{Competing Interests}

The author has no competing interests to declare.

\section{References}

\section{Ancient Sources}

Columella (Translated by E.S. Forster and E.H. Heffner 1954). On Agriculture, Vol. II, Books 5-9. Loeb Classical Library 407. Cambridge, MA: Harvard University Press.

Dionysius of Halicarnassus (Translated by E. Cary 1939). Roman Antiquities, Vol. II, Books 3-4. Loeb Classical Library 347. Cambridge, MA: Harvard University Press.

Polybius (Translated by W.R. Paton, revised by F.W. Walbank and C. Habicht 2010). The Histories, Vol. I, Books 1-2. Loeb Classical Library 128. Cambridge, MA: Harvard University Press. DOI: https://doi.org/10.4159/ DLCL.polybius-histories.2010

Strabo (Translated by H.L. Jones 1917). Geography, Vol. I, Books 1-2. Loeb Classical Library 49. Cambridge, MA: Harvard University Press. DOI: https://doi.org/10.4159/DLCL.strabo-geography.1917

Varro (Translated by W.D. Hooper and H.B. Ash 1934). On Agriculture. Loeb Classical Library 283. Cambridge: Harvard University Press. DOI: https://doi.org/10.4159/DLCL.varro-agriculture.1934

Virgil (Translated by H. Rushton Fairclough, revised by G.P. Goold 1916). Eclogues. Georgics. Aeneid: Books 1-6. Loeb Classical Library 63. Cambridge, MA: Harvard University Press. DOI: https://doi.org/10.4159/ DLCL.virgil-eclogues.1916

\section{Modern Sources}

Albarella, U. 2005. Alternate fortunes? The role of domestic ducks and geese from Roman to Medieval times in Britain. In: G. Grupe and J. Peters (eds) Feathers, Grit and Symbolism: Birds and Humans in the Old and New Worlds. Rahden: Verlag Marie Leidorf: 249-258.

Albarella, U., Manconi, F., and Trentacoste, A. 2011. A week on the plateau: pig husbandry, mobility and resource exploitation in Central Sardinia. In: U. Albarella and A. Trentacoste (eds) Ethnozooarchaeology: The Present and Past of Human-Animal Relationships. Oxford: Oxbow Books: 143-159. DOI: https://doi. org/10.2307/j.ctvh1dwvg.19

Alldritt, I., Whitham-Agut, B., Sipin, M., Studholme, J., Trentacoste, A., Tripp, J.A., Cappai, M.G., Ditchfield, P., Devièse, T., Hedges, R.E.M., and McCullagh, J.S.O. 2019. Metabolomics reveals diet-derived plant polyphenols accumulate in physiological bone. Scientific Reports 9(1): 8047. DOI: https://doi. org/10.1038/s41598-019-44390-1

Barker, G. 1976. Animal husbandry at Narce. In: T.W. Potter A Faliscan Town in South Etruria: Excavations at Narce 1966-71. London: British School at Rome: 295-307. 
Barker, G. 1988. Archaeology and the Etruscan countryside. Antiquity 62: 722-785. DOI: https://doi. org/10.1017/S0003598X00075220

Barker, G. 1989. Animals, ritual and power in ancient Samnium. In: P. Meniel (ed.) Animal et pratiques religieuses: les manifestations matérielles. Anthropozoologica numéro spécial 3: 111-117.

Becker, H. 2009. The economic agency of the Etruscan temple: elites, dedications and display. In: M. Gleba and H. Becker (eds) Votives, Places, Rituals in Etruscan Religion. Studies in Honour of Jean MacIntosh Turfa. Leiden: Brill: 85-100. DOI: https://doi.org/10.1163/ej.9789004170452.i-292.49

Becker, H. 2017. Economy, 580-450 BCE. In: A. Naso (ed.) Etruscology. Berlin-Boston: De Gruyter: 10131030. DOI: https://doi.org/10.1515/9781934078495

Bedini, E. 1997. I rest faunistici. Tarquinia: Testimonianze archeologiche e ricostruzione storica. In: M. Bonghi Jovino and C.C. Treré (eds) Scavi sistematici nell'abitato (Campagne 1982-1988). Rome: L'Erma di Bretschneider: 103-144.

Bergamini, M. (ed.) 1991. Gli Etruschi maestri di idrualica. Perugia: Electa.

Bertani, M.G. 1995. Il "banchetto dei morti" in Etruria Padana (IX-IV sec. aC): risorse del territorio e alimentazione nelle testimonianze funerarie. In: L. Quilici and S. Quilici Gigli (eds) Agricoltura e commerci nell'Italia antica. Rome: L'Erma di Bretschneider: 41-64.

Biella, M.C. 2019. Gods of value: preliminary remarks on religion and economy in pre-Roman Italy. Religion in the Roman Empire 5(1): 23-45. DOI: https://doi.org/10.1628/rre-2019-0004

Boyce, G.K. 1937. Corpus of the Lararia of Pompeii. Memoirs of the American Academy in Rome 14. Rome: American Academy. DOI: https://doi.org/10.2307/4238593

Bruni, S. 2005. Il Santuario di Ortaglia nel territorio Volterrano: appunti sulle pratiche cultuali. In: M. Bonghi Jovino and F. Chiesa (eds) Offerte dal regno vegetale e dal regno animale nelle manifestazione del sacro. Rome: L'Erma di Bretschneider: 15-28.

Castellano, L., Ravazzi, C., Furlanetto, G., Pini, R., Saliu, F., Lasagni, M., Orlandi, M., Perego, R., Degano, I., Valoti, F., de Marinis, R.C., Casini, S., Quirino, T., and Rapi, M. 2017. Charred honeycombs discovered in Iron Age Northern Italy. A new light on boat beekeeping and bee pollination in pre-modern world. Journal of Archaeological Science 83: 26-40. DOI: https://doi.org/10.1016/j.jas.2017.06.005

Cifani, G. 2002. Notes on the rural landscape of central Tyrrhenian Italy in the 6th-5th c. B.C. and its social significance. Journal of Roman Archaeology 15: 247-260. DOI: https://doi.org/10.1017/S1047759400013933

Colivicchi, F., Gregori, G.L., Lanza, M., Lepone, A., Scalici, M., Trentacoste, A., and Zaccagnino, C. 2016. New excavations in the urban area of Caere. Mouseion 13: 359-450.

Corbino, C., Minniti, C., De Grossi Mazzorin, J., and Albarella, U. 2017. The role of chicken in the medieval food system: evidence from Central Italy. Tijdschrift voor Mediterrane Archeologie 56: 50-57.

Corbino, C., Minniti, C., De Grossi Mazzorin, J., and Albarella, U. In prep. Earliest evidence of chicken in Italy. In: U. Albarella, P. Baker, E. Browaeys, C. Corbino, J. Mulville, G. Poland, and F. Worley (eds) The Archaeology of Human-Bird Interactions: Essays in Honour of Dale Serjeantson, Vol. 2. Quaternary International.

Crabtree, P. 1990. Zooarchaeology and complex societies: some uses of faunal analysis for the study of trade, social status, and ethnicity. In: M.B. Schiffer (ed.) Archaeological Method and Theory. Tucson: University of Arizona Press: 155-205.

deFrance, S.D. 2009. Zooarchaeology in complex societies: political economy, status, and ideology. Journal of Archaeological Research 17(2): 105-168. DOI: https://doi.org/10.1007/s 10814-008-9027-1

De Grossi Mazzorin, J. 1985. Reperti faunistici dall'acropoli di Populonia: testimonianze di allevamento e caccia nel III secolo a.C. Rassengna di Archeologia 4: 131-171.

De Grossi Mazzorin, J. 1989. Testimonianze di allevamento e caccia nel Lazio antico tra l'VIII e il VII secolo a.C. Dialoghi di Archeologia 7(1): 125-142.

De Grossi Mazzorin, J. 1995. Economie di allevamento in Italia Centrale dalla media età del bronzo alla fine dell'età del ferro. In: N. Christie (ed.) Settlement and Economy in Italy 1500 BC to AD 1500. Oxford: Oxbow Books: 167-177.

De Grossi Mazzorin, J. 2004. I resti animali della struttura ipogea di Centocelle: una testimonianza di pratiche cultuali? In: P. Gioia and R. Volpe (eds) Centocelle I. Roma S.D.O., le indagini archeologiche. Soveria Mannelli: Rubbettino Editore: 323-329.

De Grossi Mazzorin, J. 2005. Introduzione e diffusione del pollame in Italia ed evoluzione delle sue forme di allevamento fino al Medioevo. In: I. Fiore, G. Malerba, and S. Chilardi (eds) Atti del $3^{\circ}$ Convengo Nazionale di Archeozoologia. Rome: Istituto Poligrafico e Zecca dello Stato: 351-360. 
De Grossi Mazzorin, J. and Minniti, C. 2009. L'Utilizzazione degli animal nella documentazione archeozoologica a Roma e nel Lazio dalla preistoria recente all'età classica. In: L. Drago Troccoli (ed.) Il Lazio dai Colli Albani ai Monti Lepini tra preistoria ed età moderna. Rome: Edizioni Quasar: 39-67.

De Grossi Mazzorin, J. and Minniti, C. 2017. Changes in lifestyle in ancient Rome (Italy) across the Iron Age/Roman transition: the evidence from animal remains. In: U. Albarella, M. Rizzetto, H. Russ, K. Vickers, and S. Viner-Daniels (eds) The Oxford Handbook of Zooarchaeology. Oxford: Oxford University Press: 127-146. DOI: https://doi.org/10.1093/oxfordhb/9780199686476.013.11

De Grossi Mazzorin, J. and Minniti, C. 2019a. The exploitation and mobility of exotic animals: zooarchaeological evidence from Rome. In: M.G. Allen (ed.) The Role of Zooarchaeology in the Study of the Western Roman Empire. Portsmouth: Journal of Roman Archaeology: 85-99.

De Grossi Mazzorin, J. and Minniti, C. 2019b. Variabilità dimensionale e sviluppo dei caprovini in Italia durante l'età del Ferro. In: J. De Grossi Mazzorin, I. Fiore, and C. Minniti (eds) Atti $8^{\circ}$ Convegno Nazionale di Archeozoologia (Lecce, 2015). Lecce: Università del Salento: 127-138. DOI: https://doi.org/10.1285/ i9788883051487p127

de Haas, T. 2017. Managing the marshes: an integrated study of the centuriated landscape of the Pontine plain. Journal of Archaeological Science: Reports 15: 470-481. DOI: https://doi.org/10.1016/j.jasrep.2016.07.012

Dibble, F. 2017. Politika Zoa: Animals and Social Change in Ancient Greece (1600-300 B.C.). Unpublished thesis (PhD), University of Cincinnati. https://etd.ohiolink.edu/pg_10?::NO:10:P10_ETD_SUBID:157941.

Dumézil, G. 1987. La religion romaine archaïque avec un appendice sur la religion des Étrusques. Paris: Payot.

Duval, C. 2018. Bœufs gaulois et bœufs français: morphologies animales et dynamiques économiques au cours de La Tène et des périodes historiques. Gallia 75: 141-171. DOI: https://doi.org/10.4000/gallia.3904

Farello, P. 1989a. Fiorano Modenese. Reperti faunistici. In: G. Ambrosetti, R. Macellari, and L. Malnati. (eds) Rubiera, "principi" etruschi in Val di Secchia. Reggio Emilia: Comune di Reggio Emilia: 179-184.

Farello, P. 1989b. I pozzi etruschi di Rubiera. Reperti faunistici. In: G. Ambrosetti, R. Macellari, and L. Malnati (eds) Rubiera, "principi" etruschi in Val di Secchia. Reggio Emilia: Comune di Reggio Emilia: 113-114.

Farello, P. 1990. S. Claudio. Reperti faunistici. In: G. Ambrosetti, R. Macellari, and L. Malnati (eds) Vestigia Crustunei. Insediamenti etruschi lungo il corso del Crostolo. Reggio Emilia: Tecnostampa: 133-140.

Farello, P. 1995. L'Emilia dal VI e V secolo a.C.: caccia e allevamento. In: Atti del I convegno nazionale di archeozoologia, Rovigo 5-7 marzo 1993. Rovigo: Centro Polesano di Studi Storici, Archeologici ed Etnografici: 209-234.

Frayn, J. 1984. Sheep-Rearing and the Wool Trade in Italy during the Roman Period. Liverpool: Francis Cairns.

Frayn, J. 1993. Markets and Fairs in Roman Italy: Their Social and Economic Importance from the Second Century BC to the Third Century AD. Oxford: Clarendon Press.

Frémondeau, D., Nuviala, P., and Duval, C. 2017. Pigs and cattle in Gaul: the role of Gallic societies in the evolution of husbandry practices. European Journal of Archaeology 20(3): 494-509. DOI: https://doi. org/10.1017/eaa.2016.10

Gaastra, J.S. 2014. Shipping sheep or creating cattle: domesticate size changes with Greek colonisation in Magna Graecia. Journal of Archaeological Science 52: 483-496. DOI: https://doi.org/10.1016/j. jas.2014.08.030

Guidi, A. 2018. Twenty years after "Absolute Chronology: Archaeological Europe 2500-500 BC": new data on Italian protohistory. Acta Archaeologica 89: 63-75. DOI: https://doi.org/10.1111/j.16000390.2018.12192.x

Gleba, M. 2008. Textile Production in Pre-Roman Italy. Oxford: Oxbow Books.

Gleba, M. 2012. From textiles to sheep: investigating wool fibre development in pre-Roman Italy using scanning electron microscopy (SEM). Journal of Archaeological Science 39(12): 3643-3661. DOI: https:// doi.org/10.1016/j.jas.2012.06.021

Gleba, M. 2017a. Textiles and dress. In: A. Naso (ed.) Etruscology. Berlin-Boston: De Gruyter: 485-504. DOI: https://doi.org/10.1515/9781934078495

Gleba, M. 2017b. Tracing textile cultures of Italy and Greece in the early first millennium BC. Antiquity 91(359): 1205-1222. DOI: https://doi.org/10.15184/aqy.2017.144 
Halstead, P. and Isaakidou, V. 2011. A pig fed by hand is worth two in the bush: ethnoarchaeology of pig husbandry in Greece and its archaeological implications. In: U. Albarella and A. Trentacoste (eds) Ethnozooarchaeology: The Present and Past of Human-Animal Relationships. Oxford: Oxbow Books: 161-174. DOI: https://doi.org/10.2307/j.ctvh1dwvg.20

Izzet, V. 2007. The Archaeology of Etruscan Society. Cambridge: Cambridge University Press. DOI: https:// doi.org/10.1017/СBO9780511735189

Jannot, J.-R. 2005. Religion in Ancient Etruria. Madison: University of Wisconsin Press.

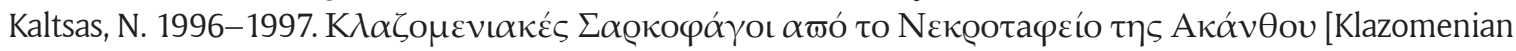
sarcophagi from Akanthos]. Archaiologikon Deltion 51-52: 35-50.

King, A.C. 1999. Diet in the Roman world: a regional inter-site comparison of the mammal bones. Journal of Roman Archaeology 12(1): 168-202. DOI: https://doi.org/10.1017/S1047759400017979

Kyselý, R. 2010. Review of the oldest evidence of domestic fowl Gallus gallus f. domestica from the Czech Republic in its European context. Acta Zoologica Cracoviensia - Series A Vertebrata 53(1-2): 9-34. DOI: https://doi.org/10.3409/azc.53a_1-2.09-34

Lentacker, A., Ervynck, A., and Van Neer, W. 2004. Gastronomy or religion? The animal remains from the mithraeum at Tienen (Belgium). In: S.J. O'Day, W. Van Neer, and A. Ervynck (eds) Behaviour Behind Bones: The Zooarchaeology of Ritual, Religion, Status and Identity. Oxford: Oxbow Books: 77-100.

MacKinnon, M. 2001. High on the hog: linking zooarchaeological, literary, and artistic data for pig breeds in Roman Italy. American Journal of Archaeology 105(4): 649-673. DOI: https://doi.org/10.2307/507411

MacKinnon, M. 2004. Production and Consumption of Animals in Roman Italy: Integrating the Zooarchaeological and Textual Evidence. Portsmouth: Journal of Roman Archaeology.

MacKinnon, M. 2010a. Cattle 'breed' variation and improvement in Roman Italy: connecting the zooarchaeological and ancient textual evidence. World Archaeology 42(1): 55-73. DOI: https://doi. org/10.1080/00438240903429730

MacKinnon, M. 2010b. "Romanizing" ancient Carthage: evidence from zooarchaeological remains. In: D.V. Campana, P. Crabtree, and S.D. deFrance (eds) Anthropological Approaches to Zooarchaeology: Colonialism, Complexity and Animal Transformations. Oxford: Oxbow Books: 168-177.

MacKinnon, M. 2014. Animals in the urban fabric of Ostia: initiating a comparative zooarchaeological synthesis. Journal of Roman Archaeology 27: 175-201. DOI: https://doi.org/10.1017/ S1047759414001202

Mattingly, D.J. and Aldrete, G.S. 2000. The feeding of Imperial Rome: the mechanics of the food supply system. In: J. Coulston and H. Dodge (eds) Ancient Rome: the Archaeology of the Eternal City. Oxford: Oxford University School of Archaeology: 142-165. DOI: https://doi.org/10.2307/j.ctvh1dk0c.11

Meadow, R. 1999. The use of size index scaling techniques for research on archaeozoological collections from the Middle East. In: C. Becker, H. Manhart, J. Peters, and J. Schibler (eds) Historia Animalium ex Ossibus. Festschrift für Angela von den Driesch. Rahden/Westf.: Verlag Marie Leidorf GmbH: 285-300.

Mellink, M.J. 1974. Excavations at Karataş-Semayük and Elmali, Lycia, 1973. American Journal of Archaeology 78(4): 351-359. DOI: https://doi.org/10.2307/502750

Meyers, G.E. 2013. Women and the production of ceremonial textiles: a reevaluation of ceramic textile tools in Etrusco-Italic sanctuaries. American Journal of Archaeology 117(2): 247-274. DOI: https://doi. org/10.3764/aja.117.2.0247

Miller, S. 2010. Two painted chamber tombs of Northern Lycia at Kizıbel and Karaburun. In: L. Summerer and A. von Kienlin (eds) Tatarl: renklerin dönüşü. Istanbul, T.C. Kültür ve Turizm Bakanlığı; Yapı Kredi Yayınları: 318-329.

Minniti, C. 2012a. Ambiente, sussistenza e l'articolazione sociale nell'talia centrale tra Bronzo medio e Primo Ferro. Oxford: Archaeopress. DOI: https://doi.org/10.30861/9781407309873

Minniti, C. 2012b. Offerte rituali di cibo animale in contesti funerari dell'Etruria e del Lazio nella prima età del Ferro. In: J.D.G. Mazzorin, D. Saccà, and C. Tozzi (eds) Attii del $6^{\circ}$ Convegno Nazionale di Archeozoologia. Lecce: Associazione Italiana di ArcheoZoologia: 153-161.

Morel, J.-P. 2007. Early Rome and Italy. In: R. Morris, P. Saller, and W. Scheidel (eds) The Cambridge Economic History of the Greco-Roman World. I. Cambridge: Cambridge University Press: 485-510. DOI: https://doi.org/10.1017/CHOL9780521780537.019

Nieto-Espinet A. 2018. Element measure standard biometrical data from a cow dated to the Early Bronze Age (Minferri, Catalonia) [digital resource]. DOI: https://doi.org/10.13140/RG.2.2.13512.78081 
Nijboer, A. 1998. From Household Production to Workshops: Archaeological Evidence for Economic Transformations, Pre-monetary Exchange and Urbanisation in Central Italy from 800 to 400 BC. Groningen: Groningen Institute of Archaeology.

Nijboer, A. 2004. Characteristics of emerging towns in Central Italy, 900/800 to 400 BC. In: P. Attema (ed.) Centralization, Early Urbanization and Colonization in First Millenium BC Italy and Greece. Part I: Italy. Leuven: Peeters: 137-156.

Nijboer, A. 2017a. Economy, 10th cent.-730 BCE. In: A. Naso (ed.) Etruscology. Berlin-Boston: De Gruyter: 795-810. DOI: https://doi.org/10.1515/9781934078495-043

Nijboer, A. 2017b. Economy, 730-580 BCE. In: A. Naso (ed.) Etruscology. Berlin-Boston: De Gruyter: 901920. DOI: https://doi.org/10.1515/9781934078495-049

Perkins, P. 2012. Production and commercialization of wine in the Albegna Valley. In: A. Ciacci, P. Rendini, and A. Zifferero (eds) Archeologia della vite e del vino in Toscana e nel Lazio: dalle tecniche dell'indagine archeologia alle prospettive della biologia molecolare. Borgo San Lorenzo: All'Insegna del Giglio: 413-426.

Petropoulou, M.-Z. 2008. Animal Sacrifice in Ancient Greek Religion, Judaism, and Christianity, 100 $B C$ to $A D$ 200. Oxford: Oxford University Press. DOI: https://doi.org/10.1093/acprof:oso/9780 199218547.001 .0001

Pieraccini, L.C. 2014. The ever elusive Etruscan egg. Etruscan Studies 17(2): 267-292. DOI: https://doi. org/10.1515/etst-2014-0015

Potts, C.R. 2015. Religious Architecture in Latium and Etruria, c. 900-500 BC. Oxford: Oxford University Press.

Rast-Eicher, A. and Bender Jørgensen, L. 2013. Sheep wool in Bronze Age and Iron Age Europe. Journal of Archaeological Science 40(2): 1224-1241. DOI: https://doi.org/10.1016/j.jas.2012.09.030

Redding, R.W. 2015. The pig and the chicken in the Middle East: modeling human subsistence behavior in the archaeological record using historical and animal husbandry data. Journal of Archaeological Research 23(4): 325-368. DOI: https://doi.org/10.1007/s10814-015-9083-2

Riedel, A. 1978. Notizie preliminari sullo studio della fauna di Spina. Atti dell'Accademia delle Scienze di Ferrara 55: 27-33.

Riedel, A. 1988. Evolution of the animal populations of northeastern Italy from the Late Neolithic to the Middle Ages. Archaeozoologia 2(1, 2): 319-328.

Riedel, A. 1994. Archeozoological investigations in north-eastern Italy: the exploitation of animals since the Neolithic. Preistoria Alpina 30: 43-94.

Riva, C. 2010. The Urbanisation of Etruria, Funerary Pratices and Social Change, 700-600 BC. Cambridge: Cambridge University Press. DOI: https://doi.org/10.1017/CBO9781316136515

Rives, J.B. 2019. Animal sacrifice and euergetism in the Hellenistic and Roman polis. Religion in the Roman Empire 5(1): 83-102. DOI: https://doi.org/10.1628/rre-2019-0006

Rizzetto, M., Crabtree, P.J., and Albarella, U. 2017. Livestock changes at the beginning and end of the Roman period in Britain: issues of acculturation, adaptation, and 'improvement'. European Journal of Archaeology 20(3): 535-556. DOI: https://doi.org/10.1017/eaa.2017.13

Roselaar, S. 2017. Economy and demography of Italy. In: G. Farney and G. Bradley (eds) The Peoples of Ancient Italy. Berlin-Boston: De Gruyter: 173-190. DOI: https://doi.org/10.1515/9781614513001-010

Ryder, M.L. 1992. The interaction between biological and technological change during the development of different fleece types in sheep. Anthropozoologica 16: 131-140.

Scheid, J. 2007. Sacrifices for gods and ancestors. In: J. Rüpke (ed.) A Companion to Roman Religion. Oxford: Wiley: 263-271. DOI: https://doi.org/10.1002/9780470690970.ch19

Smith, C. 1996. Early Rome and Latium: Economy and Society c. 1000 to 500 BC. Oxford: Clarendon Press.

Sorrentino, C., di Giuseppe, Z., and Manzi, F. 2000. Materiale osteologico animale. In: S. Bruni (ed.) Le navi antiche di Pisa. Ad un anno dall'inizio delle ricerche. Florence: Polistampa: 329-342.

Steingräber, S. 2006. Abundance of Life, Etruscan Wall Painting. (Translated by R. Stockman.) Los Angeles: Getty Publications.

Steingräeber, S. 2010. Etruscan tomb painting of the Archaic period and its relationship to the painting in Ionian Asia Minor. In: L. Summerer and A. von Kienlin (eds) Tatarlt: renklerin dönüşü. Istanbul: T.C. Kültür ve Turizm Bakanlığı; Yapı Kredi Yayınları: 354-367.

Terrenato, N. 2019. The Early Roman Expansion into Italy: Elite Negotiation and Family Agendas. Cambridge: Cambridge University Press. DOI: https://doi.org/10.1017/9781108525190 
Toynbee, J.M.C. 1973. Animals in Roman Life and Art. London: Thames and Hudson.

Trentacoste, A. 2014. The Etruscans and their Animals: the Zooarchaeology of Forcello di Bagnolo San Vito (Mantova). Unpublished thesis (PhD), University of Sheffield. http://etheses.whiterose.ac.uk/6553/.

Trentacoste, A. 2016. Etruscan foodways and demographic demands: contextualizing protohistoric livestock husbandry in Northern Italy. European Journal of Archaeology 19(2): 279-315. DOI: https://doi.org/10.1 179/1461957115Y.0000000015

Trentacoste, A., Nieto-Espinet, A., and Valenzuela-Lamas, S. 2018. Pre-Roman improvements to agricultural production: evidence from livestock husbandry in late prehistoric Italy. PLOS ONE 13(12): e0208109. DOI: https://doi.org/10.1371/journal.pone.0208109

Trentacoste, A., Lightfoot, E., Le Roux, P., Buckley, M., Kansa, S.W., Esposito, C., and Gleba, M 2020. Heading for the hills? A multi-isotope study of sheep management in first-millennium BC Italy. Journal of Archaeological Science: Reports 29: 102036. DOI: https://doi.org/10.1016/j.jasrep.2019.102036

Valenzuela-Lamas, S. and Albarella, U. 2017a. Animal husbandry across the Western Roman Empire: changes and continuities. European Journal of Archaeology 20(3): 402-415. DOI: https://doi.org/10.1017/ eaa.2017.22

Valenzuela-Lamas, S. and Albarella, U. (eds) 2017b. Animal Husbandry in the Western Roman Empire: A Zooarchaeological Perspective. European Journal of Archaeology 20(3). DOI: https://doi.org/10.1017/ eaa.2017.22

Wealleans, A.L. 2013. Such as pigs eat: the rise and fall of the pannage pig in the UK. Journal of the Science of Food and Agriculture 93(9): 2076-2083. DOI: https://doi.org/10.1002/jsfa.6145

Wilkens, B. 1997. La faune du site romaine de Calvatone, Cremona (Italie). Anthropozoologica 25-26: 611-616.

Zifferero, A. 2017. Settlement patterns and land use. In: A. Naso (ed.) Etruscology. Berlin-Boston: de Gruyter: 1339-1358. DOI: https://doi.org/10.1515/9781934078495

How to cite this article: Trentacoste, A. 2020. Fodder for Change: Animals, Urbanisation, and Socio-Economic Transformation in Protohistoric Italy. Theoretical Roman Archaeology Journal, 3(1): 1, pp.1-17. DOI: https://doi. org/10.16995/traj.414

Published: 26 June 2020

Copyright: ( $) 2020$ The Author(s). This is an open-access article distributed under the terms of the Creative Commons Attribution 4.0 International License (CC-BY 4.0), which permits unrestricted use, distribution, and reproduction in any medium, provided the original author and source are credited. See http://creativecommons.org/ licenses/by/4.0\% 